\title{
THE POSSIBILITIES OF MYOCARDIUM SCINTIGRAPHY WITH 99MTC-MIBI AND 123I-MIBG FOR OPTIMIZATION OF THE ICD DEFIBRILLANT ELECTRODE LOCATION IN PATIENTS WITH CAD: THE COMPARATIVE STUDY
}

\author{
Atabekov T.A., Sazonova S.I, Batalov R.E., Hlynin M.S., Gutor S.S., Shartsman A.D., \\ Popov S.V.
}

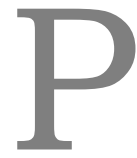

urpose. . The aim of the research was to study the possibility of using the myocardium SPECT with 99mTc-MIBI and myocardium scintigraphy with 123Imetaiodobenzylguanidine (123I-MIBG) in order to optimize the location choice of the cardioverter defibrillator (ICD) defibrillating electrode (DE) in patients with coronary artery diseases (CAD).

Materials and methods. The study included 80 patients (men - 68, women - 12, aged $65.0 \pm 7.3$ years) with CAD, who had indications for ICD implantation. Patients were divided into 3 groups. The first group consisted of 26 patients who underwent SPECT with $99 \mathrm{mTc}-\mathrm{MIBI}$ at rest, and the implantation of DE of ICD was performed taking into account the scintigraphic results.

The second group consisted of 27 patients who underwent myocardial scintigraphy with 123I-MIBG and ICD implantation was performed taking into account the results of this study. The third group included 27 patients to whom DE was implanted only on the basis of generally accepted electrophysiological criteria. The groups were compared by electrophysiological indices of the efficiency of the DE implantation at the 1st, 7th and 31st days after the operation.

Results. Significant differences were found for the majority of electrophysiological indices on the 1 st, 7 th and 31 st days after the operation between 1 and 3 groups. In addition, in the first group, the degree of perfusion impairment in the septal segment (scores) in patients to whom the DE was implanted into the apical position was closely correlated with the threshold of electrical stimulation (PES) on the 1 st $(p<0.05, R=0.725)$, the 7 th $(p<0.05$, $R=0.805)$ and the 31 st day $(p<0.05, R=0.922)$. In the same group, in patients to whom $\mathrm{DE}$ was implanted into a septal position, the degree of perfusion defects in the apical segment correlated with PES at the 7th $(p<0.05, R=0.660)$ and 31 st (for $p<0.05 R=0,843$ ) day.

There were no significant differences in the majority of the electrophysiological indices on the 1st, 7 th and 31 st days after the operation between the 2 nd and 3rd groups. In patients to whom the DE was implanted into the apical position, the score of the 123I-MIBG accumulation defects in the septal segment correlated only with the index of the ventricular signal amplitude on the first day $(p<0.05, R=0.523)$. However, in the same group, in patients to whom the DE was implanted into the septal position, no significant correlations between electrophysiological indices and the score of 123I-MIBG accumulation defects were found.

Conclusion. Myocardial SPECT with 99mTc-MIBI with detailed evaluation of perfusion defects in the apical and septal segments of the heart ventricles allows optimizing the choice of the site of $\mathrm{DE}$ implantation in patients with CAD. The use of the 123I-MIBG scintigraphy for choosing the place of $\mathrm{DE}$ implantation did not result at significant improvement of electrophysiological parameters in the examined category of patients.

ICD.

Keywords: myocardium scintigraphy, 99mTc-MIBI, ${ }^{123}$ I-MIBG, defibrillating electrode,

Corresponding author: Atabekov T.A., e-mail: kgma1011@mail.ru

For citation: Atabekov T.A., Sazonova S.I, Batalov R.E., Hlynin M.S., Gutor S.S., Shartsman A.D., Popov S.V. The possibilities of myocardium scintigraphy with 99mtc-mibi and 123i-mibg for optimization of the icd defibrillant electrode location in patients with cad: the comparative study. REJR 2018; 8 (1):75-84. DOI:10.21569/2222-7415-2018-8-1-75-84.

Received: $\quad 04.12 .2017 \quad$ Accepted: 29.12.2017 


\title{
СРАВНИТЕАЬНОЕ ИССАЕАОВАНИЕ ВОЗМОЖНОСТИ ПРИМЕНЕНИЯ РЕЗУАЬТАТОВ СЦИНТИГРАФИИ МИОКАРАА С 99МТС-МИБИ И 123І-МИБГ ААЯ ОПТИМИЗАЦИИ ВЫБОРА МЕСТА ИМПААНТАЦИИ АЕФИБРИМИИРУЮЩЕГО ЭАЕКТРОАА КААИОВЕРТЕРА-АЕФИБРИААЯТОРА У БОАЬНЫХ ИБС
}

\author{
Атабеков Т.А., Сазонова С.И., Баталов Р.Е., Хлынин М.С., Гутор С.С., \\ Шварцман А.А., Попов С.B.
}

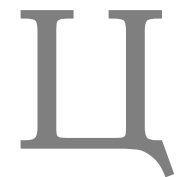

емь исследования. В сравнительном аспекте исследовать возможность применения результатов однофотонной эмиссионной компьютерной томографии (ОФЭКТ) миокарда с 99mТс-метокси-изобутиц-изонитримом (99mTcМИБИ) и 123І-метайод-бензимгуанидином (123I-МИБГ) дмя оптимизации выбора места имплантации дефибримцирующего электрода (ДЭ) кардиовертерадефибримлятора (ИКД) у больных ишемической болезнью (ИБС).

Материамы и методы. В исследование было включено 80 пациентов (мужчин

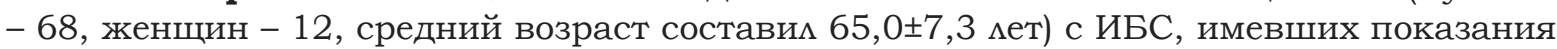
дмя имплантации ИКД. Пациенты были раздемены на 3 группы. Первую группу составили 26 больных, которым была выполнена ОФЭКТ с 99mТс-МИБИ в условиях физиомогического покоя, а имплантацию дефибримлирующего электрода (ДЭ) кардиовертера-дефибримлятора (ИКД) выполняли с учетом результатов ОФЭКТ с 99mТс-МИБИ. Вторую группу составили 27 больных, которым была проведена сцинтиграфия миокарда с 123І-МИБГ и имплантацию ИКД проводими с учетом результатов данного исследования. Третья группа включала 27 пациентов, которым имплантацию ДЭ проводими только на основании общепринятых электрофизиологических критериев. Группы сравнивали по электрофизиологическим показателям эффективности установки ДЭ на 1-е, 7-е и 31-е сутки после операции.

Резумьтаты. Между 1 и 3 группами были выявцены достоверные разцичия по большинству исследуемых электрофизиологических показателей на 1-е, 7-е и 31-е сутки после операции. Кроме того, в первой группе у пациентов, которым дефибрим^ирующий электрод (ДЭ) был имплантирован в апикальную позицию, степень нарушения перфузии в септальном сегменте (количество балмов) тесно коррелировала с показателем порога эмектрической стимуляции (ПЭС) на 1-е (при p<0,05 R=0,725), 7-е (при $\mathrm{p}<0,05 \mathrm{R}=0,805)$ и 31-е сутки (при $\mathrm{p}<0,05 \mathrm{R}=0,922)$. В этой же группе, у больных, которым ДЭ был имплантирован в септальную позицию, степень нарушения перфузии в апикальном сегменте коррелировала с ПЭС на седьмые (при $\mathrm{p}<0,05 \mathrm{R}=0,660$ ) и 31-е (при $\mathrm{p}<0,05 \mathrm{R}=0,843$ ) сутки.

Между 2 и 3 группами достоверных разцичий по большинству исследуемых эмектрофизиологических показателей на 1-е, 7-е и 31-е сутки после операции выявцено не было. У пациентов, которым ДЭ бым имплантирован в апикальную позицию, выраженность дефектов аккумуляции 123І-МИБГ в септальном сегменте (количество бамлов) коррелировала мишь с показателем амплитуды желудочкового сигнала на первые сутки (при р<0,05 R=0,523). Однако в этой же группе, у больных, которым Дэ был имплантирован в септальную позицию, значимых корреляционных связей между электрофизиологическими показателями и выраженностью нарушения аккумуляции 123І-МИБГ выявлено не было.

Закмючение. ОФЭКТ миокарда с 99mТс-МИБИ с детальной оценкой нарушения перфузии в апикальном и септальном сегментах желудочков сердца позволяет оптимизировать выбор места имплантации ДЭ у больных ИБС. Применение результатов сцинтиграфического исследования миокарда с 123I-МИБГ для выбора места имплантации ДЭ не позволимо достичь значимого улучшения электрофизиологических показателей у исследуемой категории больных.

Ключевые слова: сцинтиграфия миокарда, 99mТс-МИБИ, ${ }^{123} \mathrm{I}-\mathrm{MИБГ,} \mathrm{дефибрим-}$ мирующий электрод, имплантируемый кардиовертер-дефибримлятор.

Контактный автор: Атабеков Тариель Абдимазимович, e-mail: kgma1011@mail.ru

ФГБНУ «Томский НИМЦ РАН», НИИ кардиологии. г. Томск, Россия. 
Для иитирования: Атабеков Т.А., Сазонова С.И., Баталов Р.Е., Хльнин М.С., Гутор С.С., Швариман А.Д., Попов С.В. Сравнительное исследование возможности применения результатов сиинтиграфии миокарда с 99mтс-миби и $123 і$-мибг для оптимизаиии выбора места имплантаиии дефибриллируюшего электрода кадиовертера-дефибриллятора у больных ИБС. REJR 2018; 8 (1):75-84. DOI:10.21569/2222-74152018-8-1-75-84.

\section{Статья получена: $\quad$ 04.12.2017 Статья принята: $\quad$ 29.12.2017}

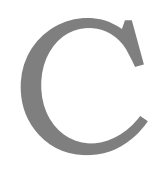

urrently the implantation of cardioverter-defibrillator (ICD) is the main method of sudden cardiac death preventing. For the effective operation of this type of device, it is extremely important to choose an optimal location for of the ICD defibrillating electrode (DE) in the heart.

To date, DE is most often implanted in the apical or septal position [1] on the basis of electrophysiological criteria, including intraoperative assessment of the of the ventricular signal amplitude (VSA) [2], the threshold of electrical stimulation (TES) and electrode impedance (EI) [3].

However, for the patients with coronary artery disease (CAD), these criteria are not ideal, because they do not take into account the presence of the scar and the perfusion disturbances in the place of the electrode implantation, which in the long-term period lead to the TES increasing, inadequate perception of the intracardiac signal, and, as a result, to incorrect shocks from the ICD [4].

In this regard, it is important to find additional criteria that can determine the most suitable area for $\mathrm{DE}$ implantation in patients with CAD.

To date, various ray methods for visualization of ischemic myocardium have been proposed, such as echocardiography, computer and magnetic resonance imaging [5]. However, the most simple and reproducible method for coronary perfusion abnormalities detection is myocardial perfusion scintigraphy [6]. In recent years, the diagnostic usefulness of myocardial scintigraphy with the neurotropic tracer 123I-metaiodobenzylguanidine, which makes it possible to assess the state of myocardial sympathetic innervation, is also actively studied in patients with CAD and implanted ICD, [7, 8, 9]. There is evidence that this radiopharmaceutical (RPH) has a higher sensitivity to myocardial ischemic damage, compared to conventional perfusion radio-diagnostic tools (for example, 99mTc-methoxy-isobutylisonitrile).

In this regard, we assumed that the results of myocardium scintigraphy can serve as an additional criterion for choosing the location of ICD DE in patients with CAD.

The aim of the study was to assess and compare the possibilities of the application of the myocardium scintigraphy with 99mTc-methoxyisobutyl-isonitrile and 123Imetaiodobenzylguanidine for optimization of the choice of the location of the defibrillator electrode in patients with CAD.

\section{Patients and methods.}

The study included 80 patients (men - 68, women -12 , mean age $65.0 \pm 7.3$ years) with $\mathrm{CAD}$, a functional class of angina pectoris from I to III, heart failure from I to III according to the classification of New-York Heart Association, which had indications for implantation of the ICD. Clinical characteristics of patients are presented in Table 1. All patients before the implantation of the device were examined with standard diagnostic methods. Then the patients were divided into 3 groups that were comparable in terms of clinical characteristics.

The first group consisted of 26 patients (23 men, women-3, average age $62.8 \pm 8.0$ years) to whom additionally single-photon emission computed tomography of the heart (SPECT) with 99mTc-methoxy-isobutyl-isonitrile (99mTc-MIBI ("Technetril, 99mTc", OJSC "Diamed", Russia)) at rest was performed. In this group, ICD implantation was performed taking into account the results of the SPECT with 99mTc-MIBI.

The second group consisted of 27 patients (23 men, 4 women, average age $65.5 \pm 8.3$ years) who, in addition to standard diagnostic procedures, underwent the myocardium scintigraphy with 123I-methaiodobenzylguanidine (123I-MIBG) and ICD implantation was performed with taking into account the results (delayed scans) of this study.

The third group consisted of 27 patients (men - 22, women - 5, average age 67.2 \pm 6.4 years), to whom ICD was implanted only on the basis of generally accepted electrophysiological criteria: TES $1.0 \mathrm{~V}$ or less, VSA $5.0 \mathrm{mV}$ and more $[2,3]$.

The myocardium perfusion scintigraphy was performed at rest in the SPECT mode, in accordance with the current recommendations of the European Society of Nuclear Medicine [6], using $740 \mathrm{MBq} \mathrm{RPH}$ of $99 \mathrm{mTc}-\mathrm{MIBI}$. Images registration was performed on a double-head gamma camera Philips-Forte equipped with high-resolution colli- 
mators into a $64 \times 64$ pixel matrix.

The assessment myocardium perfusion was performed with the help of the QPS program $(\mathrm{Ce}-$ dars Sinai Medical Center, USA), with the construction of a 20 segment polar map of the left ventricle (LV) of the "bull eye" type.

The analysis of regional myocardial perfusion defects in each segment was performed on a 5-point scale (from 0 to 4 ) and the overall index of summed rest score (SRS\%) was calculated as the sum of scores in the hypoperfused segments, expressed as a percentage of the maximum possible score in all 20 segments of the polar map $(80$ points) of the myocardium.

Since DE was implanted through the right ventricle, myocardial perfusion defects the in the apical and septal segments, which are joint to the left and right ventricles were assessed separately according to 5-point scale (from 0 to 4$)$ ), and these results were included in the subsequent analysis. A detailed evaluation of perfusion abnormalities in other LV areas was not performed.

Myocardium scintigraphy with 123I-MIBG was performed at both planar and SPECT modes at 20 min (early study) and 4 hours after injection (delayed study) of $111-370 \mathrm{MBq}$ of the RPH. All patients underwent thyroid blockade using Lugol's solution for 3 days before the study and 3 days after the study with 123I-MIBG (5 drops of Lugol's solution 3 times a day). The total sympathetic activity of the myocardium was assessed on planar images using the washout rate of the index (WR) and the heart / mediastinum index for early $(\mathrm{H} /$ $\mathrm{Me})$ and delayed (H / Md) scintigrams [9]. The processing of SPECT images was performed using the QPS program (Cedars Sinai Medical Center, USA), with the construction of a 20 segment polar map of the left ventricle (LV) of the "bull's eye" type. Regional sympathetic activity was assessed visually on using the short axis slices of the heart. The depth of the accumulation defects of the RPH was assessed using 5 score scale (from 0 to 4 ) with calculation of the summed 123I-MIBG scorer indexes at early (SMSe\%) and delayed (SMSd\%) images [9]. 123I-MIBG defects the in the apical and septal segments were assessed separately according to 5-point scale (from 0 to 4)), and these results were included in the subsequent analysis. A detailed evaluation of $\mathrm{RPH}$ uptake defects in other LV areas was not performed.

In the 1 st and 2 nd groups ICD implantation was performed under fluoroscopic control, with $\mathrm{DE}$ active fixation in the right ventricular as follows: in septal position - in the presence of perfusion defects or delayed accumulation of 123IMIBG in the apical segments; in the apical position - if perfusion or delayed 123I-MIBG defects were in septal segments.

In cases of combined ischemic injury of the septal and apical segments, the electrode was placed in the region of the smallest damage, determined by a 5-point scintigraphic scale. In the absence of scintigraphic signs of myocardial perfusion disturbance or accumulation of 123I-MIBG, DE implantation was performed on the basis of conventional electrophysiological criteria [2, 3]. To verify the $\mathrm{DE}$ contact with endomiocardium, an intermediate evaluation of a 1.0-volt TES and an VSA of more than $5.0 \mathrm{mV}$ was performed using a Medtronic analyzer (USA).

In the third group, DE with active fixation was conducted into the cavity of the right ventricle and the area of it location was chosen depending on the electrophysiological indices [2, 3].

In all patients a checking of the DE parameters, such as TES, VSA, the electrode (EI) and the shock impedance (SHI) was performed on the 1st, 7 th and 31 st days after the ICD implantation. These parameters were compared between 1 and 3 , as well as 2 and 3 groups.

Statistical analysis of the results was performed using the Statistica 10.0 software package. To assess the normality of the data distribution, the Kolmagorov-Smirnov test was used. The arithmetic mean $(\mathrm{M})$, standard deviation (SD) were calculated. The Mann-Whitney test for independent samples and Wilcoxon for bound samples was used for groups comparing. The correlation analysis was performed using the Spearman nonparametric rank coefficient.

The study was carried out in accordance with the standards of good clinical practice (Good Clinical Practice) and the principles of the Helsinki Declaration. The study protocol was approved by the ethical committee of the Institute of Cardiology. Written informed consent was obtained from all patients.

\section{Results.}

Myocardial perfusion defects were diagnosed in $19(73.1 \%)$ patients of the 1st group, with an average SRS of $23.55 \pm 14.87 \%$. The combined ischemic injury of the septal and apical regions of the LV was detected in 16 of 19 patients (84.2\%). Among them, the predominant ischemia of the septal region was noted in $6(37.5 \%)$ patients: the number of affected segments was $2.67 \pm 1.75$ (min 2 , $\max 6$ ), the degree of damage was $5.0 \pm 4.98$ points (min $2, \max 17$ ), and the predominant ischemia of the apex - in 10 (62.5\%) of the examined persons: the number of affected segments is $2.0 \pm 0(\min 2, \max 2)$, the degree of damage is 6.0 \pm 2.46 points $(\min 2, \max 8)$. Perfusion defects in the septal region ( 1 point, 1 segment) in combination with other LV areas (except apex) were foundin $2(12.5 \%)$, in the apex (1 point, 1 segment) ) in combination with other LV areas (except septum) in 1 patient $(6.25 \%)$. In 14 (54\%) patients of this group, DE was implanted in the apical position, and in $12(46 \%)$ - in septal.

In the second group, defects of 123I-MIBG 
accumulation were detected in all 27 (100\%) of the examined patients, both on early and delayed images. In the early scintigrams, the average SMSe\% was $25.75 \pm 15.43 \%, \mathrm{H} / \mathrm{Me}-1.86 \pm 0.38$. On the delayed images, $\mathrm{SMSd} \%$ was equal to $33.75 \pm$ $22.42 \%, \mathrm{H} / \mathrm{Md}=1.81 \pm 0.39$. The averaged WR was $36.7 \pm 30.64(\min 2.98, \max 128.5)$.

Defects in septal segments of the left ventricle were found in 20 patients (74.07\%), in the apical segments - in 21 of 27 patients (77.78\%). The combined damage of these areas was revealed in $17(62.96 \%)$ of the examined subjects: the preferential defects in the septal region - in $11(64.71 \%)$ $(7.0 \pm 5.19$ points $(\min 2, \max 12)$ on delayed $\mathrm{im}-$ ages, $5,5 \pm 4,14(\min 2, \max 10)$ - in the early ones), the preferential defects in the apex - in 6 (35.29\%) patients $(5.2 \pm 2.66$ points ( $\min 1, \max$ 8) on delayed images , $4.37 \pm 2.83$ points (min 1, $\max 8$ ) - on the early). In 15 patients (55\%) DE was implanted into the apical position, $12(45 \%)$ into the septal.

The results of the electrophysiological examination of patients of all three groups on the 1st, 7 th and 31 st days after the operation are presented in Tables 2-4. Thus, between 1 and 3 groups, at all terms, significant differences were found in the majority of the electrophysiological parameters. At the same time, there were no significant differences between groups 2 and 3 on studied electrophysiological parameters.

A month later, when checking the parameters of the ICD in the first group of patient device triggers, dislocations, electrode damage, disturbance of detection, unmotivated shocks were not registered. In 13 patients, paroxysms of unstable ventricular tachycardia were documented, stopping spontaneously. In patients who were implanted DE in the apical position, the degree of perfusion disorder in the septal segment (the number of scores) closely correlated with the TES at the 1 st $(\mathrm{p}<0.05, \mathrm{R}=0.725), 7$ th $(\mathrm{p}<0.05, \mathrm{R}=$ $0.805)$ and the 31 st day $(p<0.05, R=0.922)$. In the same group, in patients to whom DE was implanted into the septal position, the degree of perfusion disorder in the apical segment correlated with the TES at the 7 th $(p<0.05, R=0.660)$ and 31-st (for $\mathrm{p}<0,05 \mathrm{R}=0.843$ ) day. A clinical example and scintigrams are shown in Fig. 1.

In the second group, a month after device implantation, no DE dislocations, electrode damage, detection disturbances, unmotivated shocks were observed. In 14 patients, paroxysms of unstable ventricular tachycardia stopping spontaneously were documented. In patients to whom DE was implanted into the apical position, the severity of 123I-MIBG accumulation defects in the septal segment (the number of scores) correlated with the VSA at the first day (at $\mathrm{p}<0.05 \mathrm{R}=0.523$ ) after operation. However, in the same group, in patients with DE, implanted into the septal posi- tion, there were no significant correlations between the electrophysiological indices and the severity of RPH accumulation defects. A clinical example and scintigrams are shown in Fig. 2.

The scheduled checking of the ICD parameters in the third group revealed unmotivated shocks associated with a low amplitude of the VSA in 2 patients. Dislocations, to the electrode were also not observed. In 5 patients, paroxysms of unstable ventricular tachycardia which stopped spontaneously were registered.

\section{Discussion.}

Optimization of the choice of the DE location in patients with CAD is an actual problem, because generally accepted for this purpose criteria based on the determination of TES, the VSA and EI, do not take into account the severity of the perfusion disorder in the most frequently used for DE implantation right ventricular regions - the septal and apical segments [1]. In clinical practice, a visual determination of the ischemic myocardium size is performed using echocardiography by the assessment of number of hypo- and akinetic segments. However, this method is operatordependent. Visualization of scar in the heart muscle is also possible with the use of computed tomography and magnetic resonance imaging [5]. The use of this method, despite its high accuracy and informativeness, is limited by the high cost and complexity of cardiac protocols. Myocardium perfusion scintigraphy remains the most simple and reproducible method [6, 10] for ischemic tissue detecting, allowing quantitative assessment of perfusion disorders. We hypothesized that in patients with CAD and ICD such indexes as TES, the VSA and EI depends on the severity of ischemic damage to the heart muscle, and the results of myocardium scintigraphy can serve as an additional criterion for choosing the region for DE implantation.

In order to confirm or disprove this hypothesis, we compared the main electrophysiological parameters of DE (TES, VSA, EI and SHI), in patients to whom DE was implanted using the results of the myocardium scintography with $99 \mathrm{mTc}$ TMIBI or ${ }^{123}$ I-MIBG, and without their use, and also investigated the correlation between scintigraphic and electrophysiological indices.

The results of the analysis showed a much higher efficiency of ICD implantation among patients in whom the choice of the DE location was optimized in accordance with the data of the myocardium SPECT with 99mTc-MIBI. We found significant differences between the groups for TES and the VSA on the first, seventh and 31st days after operation. In addition, a close direct correlation was established between the degree of perfusion defects in septal segments (in points) and TES for the first, seventh and 31st days. Also, a direct correlation was found between the degree of 


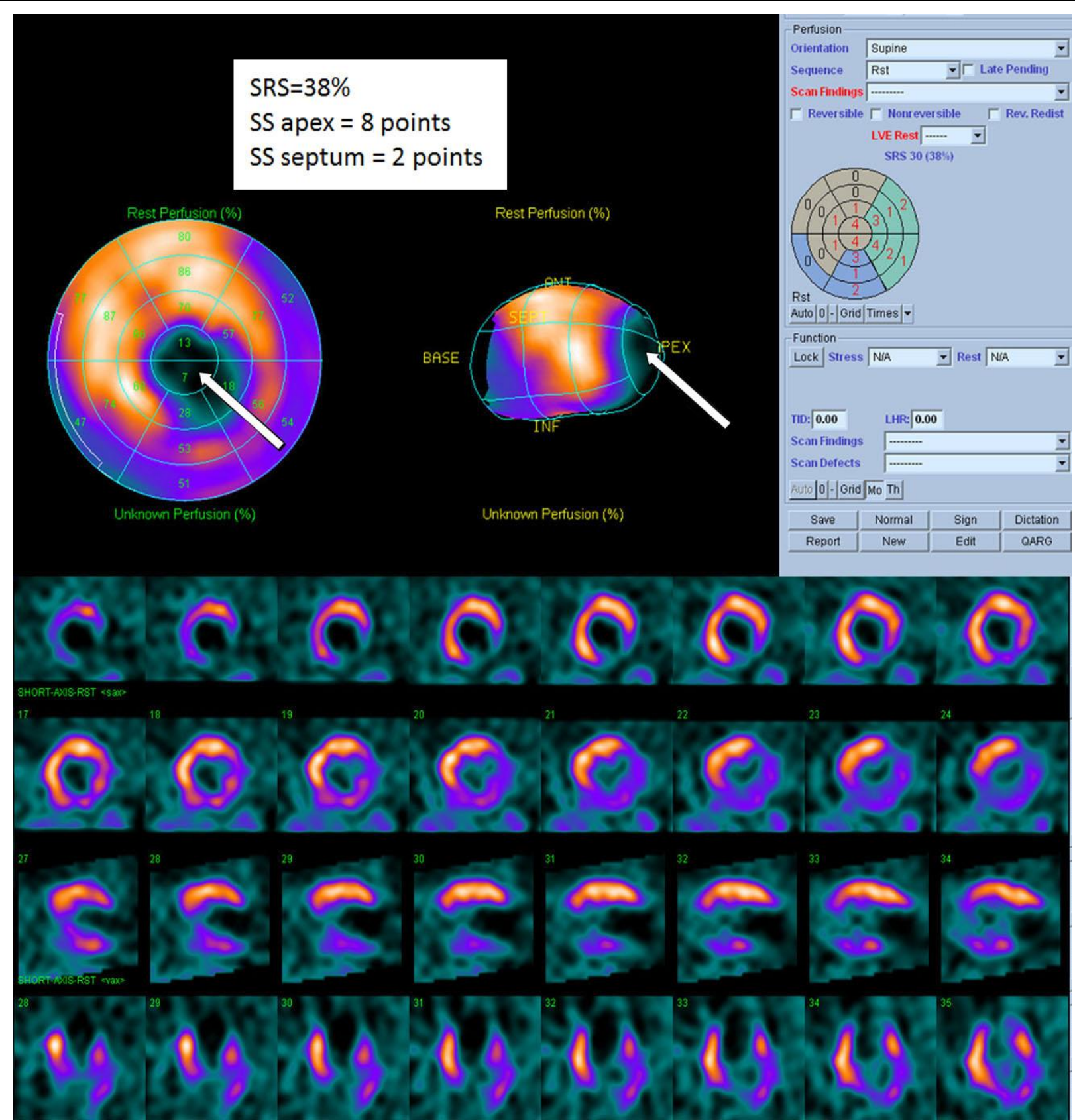

Рис. 1 (Fig. 1)

\section{Fig. 1. Myocardium perfusion scintigraphy with $99 \mathrm{mTC}-\mathrm{MIBI}$, performed at rest.}

Patient D. of 58-year-old with indications for ICD therapy. The images show hypo-aperfusion of the apex, apical parts of the posterior and lateral walls of the left ventricle (LV), as well as hypoperfusion of the middle and basal segments of the posterior and lateral wall of the LV (SRS $=38 \%$ ). Minimal changes in the area of the septum (SS $=$ 2 ), scar at the apex (SS = 8). Therefore the defibrillating electrode of the ICD was implanted to the septal position of the right ventricle. A month later, when checking the parameters of the device, dislocations, electrode damage, detection failure, unmotivated shocks were not observed.

\section{Рис.1. Перфузионная сцинтиграфия миокарАа с 99mТс-МИБИ, выполненная в условиях физиологи- ческого покоя.}

Пациент Д. 58 мет, имеющий показания дмя имплантации ИКД. Имеет место гипо-аперфузия верхушки, апикальных отделов задней и боковой области мевого желудочка ( $\Lambda$ Ж), а также гипоперфузия средних и базальных отдемов задней и боковой стенки $\Lambda$ K (SRS=38\%). Минимальные изменения в области перегородки (SS=2), аперфузия верхушки (SS=8), в связи с чем, дефибримлирующий электрод ИКД установлен в септальную позицию правого желудочка. Через месяц при проверке параметров срабатываний устройства, дислокаций, повреждения электрода, нарушения детекции, немотивированных шоков не наблюдалось. 


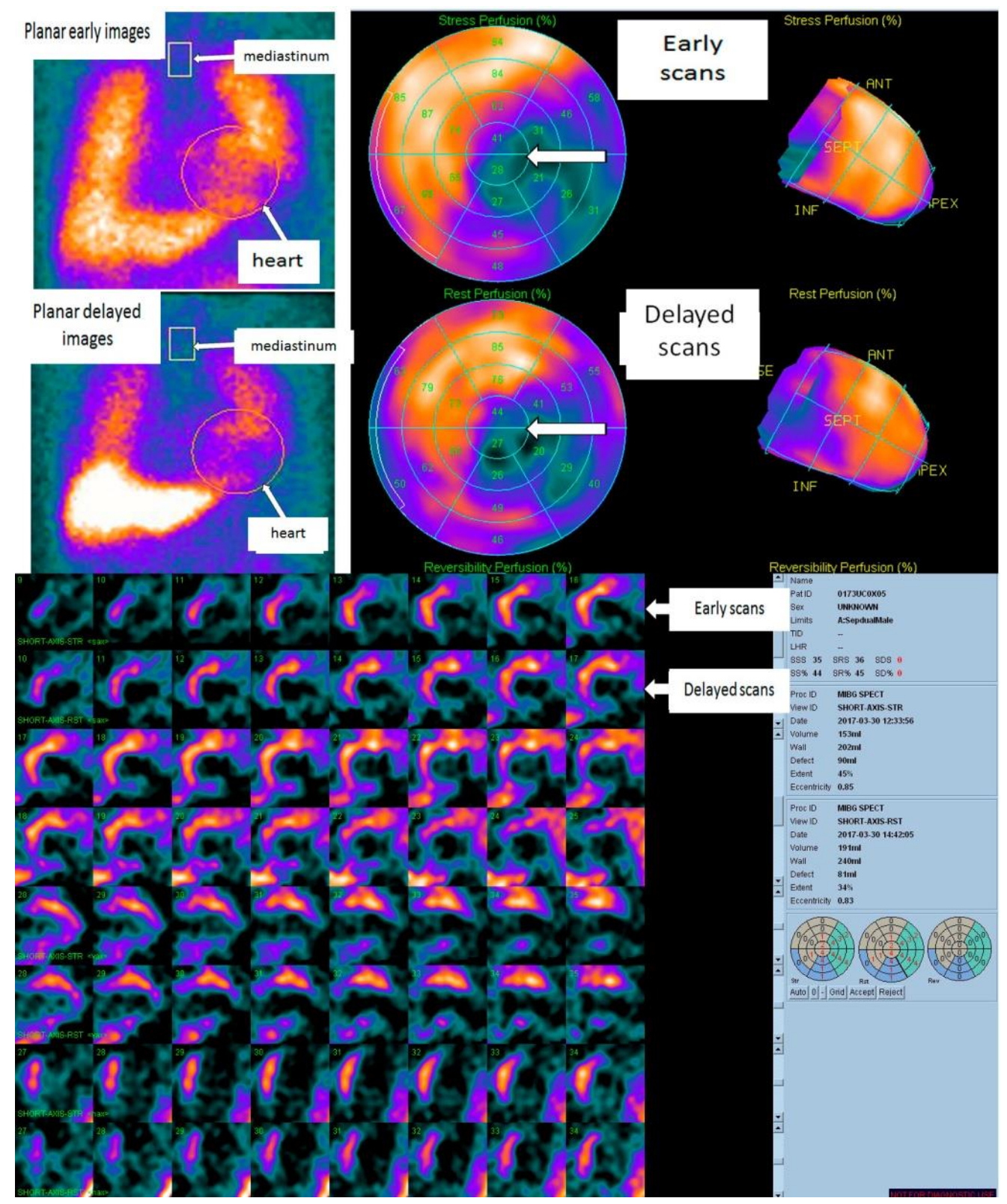

Рис. 2 (Fig. 2)

\section{Fig. 2. Myocardial scintigraphy with 99mTc-MIBG.}

Patient M. 71 years of old, having indications for ICD implantation. On planar early images, the heart / mediastinum $=1.73$, on the delayed heart / mediastinum $=1.64$; the washout rate of the radiopharmaceutical WR $=22.3$. In early and delayed SPECT scans there is deep defect of RPH accumulation in the apex, as well as in the posterior and lateral walls of the left ventricle (LV), (SMSe $=44 \%, \mathrm{SMSd}=45 \%)$. Minimal changes in the area of the septum $(\mathrm{SSd}=2)$, aperfusion of the apex $(\mathrm{SSd}=6)$. In this connection defibrillating electrode of the ICD is placed into the septal position of the right ventricle. A month later, when checking the parameters of device, no dislocations, electrode damage, detection failure, unmotivated shocks were observed.

\section{Рис. 2. Сцинтиграфия миокараа с 99mТс-МИБГ.}

Пациент М. 71 мет, имеющий показания для имплантации ИКД. На планарных ранних изображениях коэффициент сердце/средостение $=1.73$, на отсроченных сердце/средостение = 1.64 ; скорость вымывания радиофармпрепарата WR=22,3. На ранних и отсроченных томосцинтиграммах имеет место дефект аккумуляции радиофармпрепарата в области верхушки, а также задней и боковой стенки мевого желудочка ( $\Lambda Ж)$, ( $\mathrm{SMSe}=44 \%, \mathrm{SMSd}=45 \%)$. Минимальные изменения в области перегородки (SSd=2), аперфузия верхушки (SSd=6), в связи с чем, десибримлирующий электрод ИКд установлен в септальную позицию правого желудочка. Через месяц при проверке параметров срабатываний устройства, дислокаций, повреждения электрода, нарушения детекции, немотивированных шоков не наблюдалось. 
perfusion defects in the apical segments and TES on the seventh and 31 st days. These data indicate the possibility of using the results of the myocardium perfusion scintigraphy as one of the criteria for choosing the location of the DE implantation in patients with CAD.

At the same time, the benefits of using the data on regional sympathetic innervation of the myocardium for choosing the location of $\mathrm{DE}$ according to the results of scintigraphy with 123IMIBG were not revealed. In particular, there was no significant differences for the electrophysiological indices at any term after the operation with the group of patients to whom DE was implanted in accordance with generally accepted criteria. There were also no significant correlations between the degree of the RPH defects in the septal or apical regions of the left ventricle with the electrophysiological indices of the effectiveness of the DE implantation.

The myocardium scintigraphy with 123IMIBG in recent years have become very widespread, due to the proved fact of its diagnostic value in predicting cardiac death, progression of heart failure, the occurrence of life-threatening arrhythmias in patients with heart failure [11]. It is believed that the nervous tissue of the heart is more sensitive to ischemia than the muscular tissue, so the defects of accumulation of 123I-MIBG in patients with CAD are larger in size compared with the defects of accumulation of perfusion radiopharmaceuticals [12]. According to the literature, the most informative index of myocardial scintigraphy with 123I-MIBG is the ratio "heart/mediastinum", calculated from the zones of interest on planar delayed images of the heart [9].

It is also assumed that this method plays a positive role in the selection of patients for the cardioresynchronizing and ICD therapy [13]. In a number of studies, the higher significance of SPECT with 123I-MIBG was shown in comparison with myocardial perfusion scintigraphy in the prognosis of motivated shocks of ICD, implanted for primary prevention of sudden cardiac death [11].

In the presented study, on the contrary, the

\section{References:}

1. Amit G., Wang J., Connolly S.J, Glikson M., Hohnloser S., Wright D.J., et al. Apical versus non-apical lead: is ICD lead position important for successful defibrillation? J. Cardiovasc. Electrophysiol. 2016; 27 (5): 581-587.

2. Chen JH, Zhang FL, Fan L, Chen XH, Wang WW, Fu FY, Chen LL. Ideal current of injury and $R$-wave sensingvalues for identifying optimized placement of right ventricular active-fixation pacing leads. Zhonghua Xin Xue Guan Bing Za Zhi. 2016; 44 (5): 406-410.

3. Fridman V., Saponieri C., Sherif NE, Turitto G. Cardiac rhythm device threshold testing via pulse oximetry. J. Atr. Fibrillation. 2016; 8 (6): 1389-1395.
SPECT with 99mTc-MIBI performed at rest had clear advantages over neurotropic scintigraphy, in terms of determining the optimal myocardium area for the $\mathrm{DE}$ of ICD implantation in CAD patients. This is apparently due to the fact that 123I-MIBG allows you to visualize zones with impaired innervation, in which, however, viable tissue may be present. Probably, in terms of determining the success of implantation of $\mathrm{DE}$, more important are not the initial manifestations of ischemia, but the severity of fibrous changes in myocardial tissue, clearly diagnosed by perfusion scintigraphy of the myocardium.

We didn't find similar studies published in the available literature. In our opinion, the closest in fact are scientific works in which the prognostic value of myocardium perfusion scintigraphy for the effectiveness of cardiac resynchronization therapy predicting in patients with chronic heart failure and LV dysfunction was studied [14, 15, 16]. The authors Sommer A. et al. in 2016[16], showed the effectiveness of using the results of multimodal imaging methods, including myocardium perfusion scintigraphy, for choice of the location of the left ventricular electrode of a cardiac resynchronization device.

\section{Conclusion.}

The results of our study indicate that the myocardial SPECT with 99mTc-MIBI with detailed evaluation of perfusion in the apical and septal ventricular segments allows optimizing the choice of the site of DE implantation, which minimizes the violation of detection and the number of unmotivated ICD shocks in patients with CAD.

At the same time, the use of the results of myocardial scintigraphy with 123I-MIBG to select the area of DE implantation of failed to achieve a significant improvement in electrophysiological indices in the studied category of patients.

\section{Источник финансирования и конфиикт интересов.}

Авторы данной статьи подтвердили отсутствие финансовой поддержки исследования и конфцикта интересов, о которых необходимо сообщить.

4. van der Heijden A.C., Borleffs C.J., Buiten M.S., Thijssen J., van Rees J.B., et al. The clinical course of patients with implantable defibrillators: Extended experience on clinical outcome, device replacements, and device-related complications. Heart Rhythm. 2015; 12 (6): 1169-1176.

5. Pang B.J., Joshi S.B., Lui E.H., Tacey M.A., Ling L.H., Alison $J$, et al. Validation of conventional fluoroscopic and ECG criteria for right ventricular pacemaker lead position using cardiac computed tomography. Pacing Clin Electrophysiol. 2014; 37 (4): 495 504.

6. Hesse B, Tägil K, Cuocolo A, Anagnostopoulos C, Bardiés M, Bax J, Bengel F, et al. EANM/ESC procedural guidelines for 


\section{RUSSIAN ELECTRONIC JOURNAL OF RADIOLOGY}

myocardial perfusion imaging in nuclear cardiology. European Journal of Nuclear Medicine and Molecular Imaging. 2005; 32 (7): 855-897.

7. Minin S.M., Efimova I.Yu., Saushkina Yu.V., Sazonova S.I. The use of radiopharmaceuticals based on $123 \mathrm{I}$ in the evaluation of violations of sympathetic innervation and myocardial metabolism. Russian medical journal. 2013; 1: $49-52$ (in Russian).

8. Klein T, Dilsizian V, Cao Q, Chen W, Dickfeld T.M. The potential role of iodine-123 metaiodobenzylguanidine imaging for identifying sustained ventricular tachycardia in patients with cardiomyopathy. Curr Cardiol Rep. 2013; 15 (5): 359-368.

9. Flotats A, Carrió I, Agostini D, Le Guludec D, Marcassa C, Schäfers $M$, Somsen $G A$, et al. Proposal for standardization of 123I-metaiodobenzylguanidine (MIBG) cardiac sympathetic imaging by the EANM Cardiovascular Committee and the European Council of Nuclear Cardiology. Eur J Nucl Med Mol Imaging. 2010; 37 (9): 1802-12.

10. Lishmanov Yu.B., Chernov V.I. The myocardium scintigraphy in nuclear cardiology. Tomsk, TSU, 1997. 276 p. (in Russian).

11. Verschure D. O., · van Eck-Smit B. L. F., · Somsen G.A., Knol R. J. J., · Verberne H. J. Cardiac sympathetic activity in chronic heart failure: cardiac 123I-MIBG scintigraphy to improve patient selection for ICD implantation. Neth Heart J . 2016; 24

\section{Список митературы:}

1. Amit G., Wang J., Connolly S.J, Glikson M., Hohnloser S., Wright D.J., et al. Apical versus non-apical lead: is ICD lead position important for successful defibrillation? J. Cardiovasc. Electrophysiol. 2016; 27 (5): 581-587.

2. Chen JH, Zhang FL, Fan L, Chen XH, Wang WW, Fu FY, Chen $L L$. Ideal current of injury and $R$-wave sensingvalues for identifying optimized placement of right ventricular active-fixation pacing leads. Zhonghua Xin Xue Guan Bing Za Zhi. 2016; 44 (5): 406-410.

3. Fridman V., Saponieri C., Sherif NE, Turitto G. Cardiac rhythm device threshold testing via pulse oximetry. J. Atr. Fibrillation. 2016; 8 (6): 1389-1395.

4. van der Heijden A.C., Borleffs C.J., Buiten M.S., Thijssen J., van Rees J.B., et al. The clinical course of patients with implantable defibrillators: Extended experience on clinical outcome, device replacements, and device-related complications. Heart Rhythm. 2015; 12 (6): 1169-1176.

5. Pang B.J., Joshi S.B., Lui E.H., Tacey M.A., Ling L.H., Alison $J$., et al. Validation of conventional fluoroscopic and ECG criteria for right ventricular pacemaker lead position using cardiac computed tomography. Pacing Clin Electrophysiol. 2014; 37 (4): 495 504.

6. Hesse B, Tägil K, Cuocolo A, Anagnostopoulos C, Bardiés M, Bax J, Bengel $F$, et al. EANM/ESC procedural guidelines for myocardial perfusion imaging in nuclear cardiology. European Journal of Nuclear Medicine and Molecular Imaging. 2005; 32 (7): 855-897.

7. Минин С.М., Ефимова И.Ю., Саушкина Ю.В., Сазонова С.И. Использование радиофармпрепаратов на основе 123 в в оценке нарушений симпатической иннервации и метаболизма миокарда. Российский медищинский журнал. 2013; 1: 49-52.

8. Klein T, Dilsizian V, Cao Q, Chen W, Dickfeld T.M. The potential role of iodine-123 metaiodobenzylguanidine imaging for
(12): 701-708.

12. Simula S, Vanninen E, Viitanen L, Kareinen A, Lehto S, Pajunen $P$, et al. Cardiac adrenergic innervation is affected in asymptomatic subjects with very early stage of coronary artery disease. J Nucl Med. 2002; 43 (1): 1-7.

13.Dimitriu-Leen A.C., Scholte A.J., Jacobson A.F. 123I-MIBG SPECT for Evaluation of Patients with Heart Failure. J Nucl Med. 2015; 56 Suppl 4: 25S-30S. doi: 10.2967/jnumed.115.157503. 14. Lishmanov Y, Minin S, Efimova I, Chernov V, Saushkina $Y$, Lebedev D, Popov $S$. The possible role of nuclear imaging in assessment of the cardiac resynchronization therapy effectiveness in patients with moderate heart failure. Ann. Nucl. Med. 2013; 27 (4): 378-385.

15. Lebedev D.I., Krivolapov S.N., Zavadovsky K.V., Sazonova S.I., Karpov R.S., Popov S.V. The condition of the contractile function of the right ventricular myocardium, as a predictor of the effectiveness of cardiac resynchronization therapy. Russian Cardiology Journal. 2017; 7: 87-92 (in Russian).

16. Sommer A, Kronborg M.B., Nørgaard B.L., Poulsen S.H., Bouchelouche K., Böttcher M, Jensen H.K., et al. Multimodality imaging-guided left ventricular lead placement in cardiac resynchronization therapy: a randomized controlled trial. Eur. J. Heart Fail. 2016; 18 (11): 1365-1374

identifying sustained ventricular tachycardia in patients with cardiomyopathy. Curr Cardiol Rep. 2013; 15 (5): 359-368.

9. Flotats A, Carrió I, Agostini D, Le Guludec D, Marcassa C, Schäfers $M$, Somsen GA, et al. Proposal for standardization of 123I-metaiodobenzylguanidine (MIBG) cardiac sympathetic imaging by the EANM Cardiovascular Committee and the European Council of Nuclear Cardiology. Eur J Nucl Med Mol Imaging. 2010; 37 (9): 1802-12.

10. Аишманов Ю.Б., Чернов В.И. Сиинтиграфия миокарда в ядерной кардиологии. - Томск: Изд-во ТГУ, 1997, 276 с.

11. Verschure D. O., · van Eck-Smit B. L. F., · Somsen G.A., Knol R. J. J., · Verberne H. J. Cardiac sympathetic activity in chronic heart failure: cardiac 123I-MIBG scintigraphy to improve patient selection for ICD implantation. Neth Heart J . 2016; 24 (12): 701-708.

12. Simula S, Vanninen E, Viitanen L, Kareinen A, Lehto S, Pajunen $P$, et al. Cardiac adrenergic innervation is affected in asymptomatic subjects with very early stage of coronary artery disease. J Nucl Med. 2002; 43 (1): 1-7.

13. Dimitriu-Leen A.C., Scholte A.J., Jacobson A.F. 123I-MIBG SPECT for Evaluation of Patients with Heart Failure. J Nucl Med. 2015; 56 Suppl 4: 25S-30S. doi: 10.2967/jnumed.115.157503.

14. Lishmanov Y, Minin S, Efimova I, Chernov V, Saushkina $Y$, Lebedev D, Popov $S$. The possible role of nuclear imaging in assessment of the cardiac resynchronization therapy effectiveness in patients with moderate heart failure. Ann. Nucl. Med. 2013; 27 (4): 378-385.

15. Иебедев Д.И., Криволапов С.Н., Завадовский К.В., Сазонова С.И., Карпов Р.С., Попов С.В. Состояние сократительной функции миокарда правого желудочка, как предиктор эфрфективности проводимой сердечной ресинхронизируюшей терапии. Российский кардиологический журнал. 2017; 7: 87-92.

16. Sommer A, Kronborg M.B., Nørgaard B.L., Poulsen S.H., 
Bouchelouche K., Böttcher M, Jensen H.K., et al. Multimodality imaging-guided left ventricular lead placement in cardiac resyn- chronization therapy: a randomized controlled trial. Eur. J. Heart Fail. 2016; 18 (11): 1365-1374. 